\title{
The Use of Ideological Becoming in English Literature as a Means to Stimulate Students' Readiness to Speak
}

\author{
Erda Wati Bakar, Ahmad Fahimi Amir
}

\begin{abstract}
This study explores the relationship between ideological becoming and students' readiness to speak using English Literature. Learning literature can be daunting and intimidating for students. Moreover, some view the incorporation of literature in language learning is only to serve the need to impart culture and aesthetic values in students without significantly contributing to the aims of teaching and learning and students' communicative competence. In addition, some instructors find literature to be complex, thus unsuitable to be adopted in the language learning syllabus. During language learning, speaking poses the most challenging skill to master as the students have reservations and experience anxiety in expressing themselves freely and openly in sharing their thoughts. In order to promote speaking skill among the students in a literature classroom, they need to be engaged actively with activities that would facilitate and accelerate their motivation to speak. With this in view, the researcher finds Bakhtin's notion on ideological becoming may help students to be more expressive in sharing their views during lessons. Ideological becoming is a process of learning by positioning one's voice with other voices. Through this process, students are required to get their voices heard and recognized while interacting with others. Thus, this article aims to review the following, first, how is literature used in class to promote speaking skill, and second, how the notion of ideological becoming can be a useful tool in learning literature. The state of ideological becoming brings positive implication for the teaching of literature as students are encouraged to be critical and assertive in defending and justifying their responses toward any literary texts.
\end{abstract}

Index Terms: English Literature, Ideological Becoming, Motivation, Speaking Skills, Voice.

\section{INTRODUCTION}

Teaching Literature and literary analysis for the students of ESL (English as a Second Language) is perceived to be useful for language learning. Literature is claimed to be useful in improving students' level of English as not only it provides them with the knowledge of the language but also exposure to various culture represented in the texts. Different genres of literature are readily available to be manipulated in the classroom as the students are allowed to

Revised Manuscript Received on September 22, 2019.

Erda Wati Bakar, Language Centre, Universiti Pertahanan Nasional Malaysia, Kuala Lumpur, 51000, Malaysia, erdawati@upnm.edu.my

Ahmad Fahimi Amir, Language Centre, Universiti Pertahanan Nasional

Malaysia, Kuala Lumpur, 51000, Malaysia. explore different aspects of language in a much appealing and challenging manner.

As the students are exploring the language whilst learning literature, they are engaged actively in communicative activities which requires them to be fluent in the four skills of language: listening, reading, speaking and writing. For this paper, I will only be focusing on speaking skills which many studies have indicated that ESL students are mostly least confident when there is a requirement for them to speak in class. This is due to multiple factors such as lack of language input and psychological barriers. With the increase demand and need for learners of ESL to be fluent in speaking skill, I find that Bakhtin's notion of ideological becoming from his Dialogism theory may be useful to motivate students to speak. This concept is highly relevant to be adopted as part of the pedagogy of teaching literature for it not only be able to enhance students' communication skills, it may also trigger deeper interest in learning literature among ESL learners. Bakhtin's notion on ideological becoming may help students to be more expressive in sharing their views during lessons. Ideological becoming is a process of learning by positioning one's voice with other voices. Through this process, students are required to get their voices heard and recognized while interacting with others. Learners need to assert their own voices through active interaction (i.e group discussion) with other voices (i.e peers). By developing and claiming authority of their own voices, not only it may improve their confident level and motivation to speak up, also transform them to be matured learners.

Thus, this concept paper aims to answer the following, first, how is literature used in class to promote speaking skill, and second, how the notion of ideological becoming can be a useful tool in learning literature.

\section{LITERATURE REVIEW}

\section{A. Values of English Literature in ESL classes}

Literature is argued to bring discourse opportunities for students to develop specific language functions as well as improve their language proficiency. (1) asserts that literature is a useful resource to impart the four basic language skills (Reading, Listening, Speaking and Writing) to students by having it integrated into proficiency lessons. However, he argued that the main focus should not be to merely focus 
on oral and written language use, but it should lean more towards creating "referential and interactional meaning". Studies by (2) and (3) showed that through the learning of literature, students are nurtured to be eloquent in expressing their ideas in creative, critical and analytical manner. This is due to literature functions as a mean to expand students' schemata by allowing them "to question, interpret, connect and explore" (3). (4) in his study further clarified the values of Literature from the perception of communicative approach, in which he asserted that effective and meaningful language learning can be initiated as learners actively engage in the process of meaning negotiation through discussion on issues like ethics, politics, and media. The process of negotiating for meaning during literature lessons fosters "self-awareness and identity" as learners interact with new linguistic aspects and different culture (5).

Further, (6) in his studies maintained that literature is an effective tool that enable students to internalize the target language, thus improve their comprehension on English linguistic system, awareness on the use of idiomatic expressions in literary works and competence on cultural aspects (1). In another study, (7) explores on the application of literature in class discussion and the manner it aids students advanced language functions. They asserted that a literature lesson which focused on "close textual reading and interpretive discussion" (p. 196) is deemed to be suitable to develop students' speaking skills at advance level. Similar view is expressed by (5) as he argues that during a literature lesson, students become active participants whilst deducing meaning from the text. Learners are expected to approach the text through their own point of view, utilizing their prior knowledge and employing any language and methodological tools that may aid them during the process of analyzing and interpreting a literary text. Earlier (8) in reviewing the changing role of literature in foreign language teaching argued that through the interaction process, in which learners are required to participate in group discussion, while constructing and negotiating the "appropriate schemata of understanding" in order to derive meaning from the text in its "discursive and aesthetic structure" may nurture learners to be more confident in expressing their views within an atmosphere of mutual respect.

(9) in his article A Review on Literature and its Place in Malaysia's Education stated that literature is not only a source for language teaching but it carries much superior values. Learners of literature not only gain linguistic benefit, their mastery on literacy is useful in supporting their life-long learning. In addition, literature is also perceived to be a useful tool in inculcating positive outlook and appreciation toward the culture of others, simultaneously help to forge unity as learners are being educated on the different values and identities in a multicultural nation (10).

\section{B. Factors Affecting Speaking Skills}

To be able to speak well is crucial for any English language learners. This skill is claimed to be one of the most important skills to be mastered among the four language skills. One of the aims of English language teaching is to equip students with the ability to communicate effectively in the target language. It is imperative for any language training program to prepare and equip learners with speaking skill that will enable them to interact with others without being overwhelmed by apprehension, thus confidently express their views and ideas (11). Yet many learners admitted that their communicative skills are hampered due to lack of linguistic items as well as the opportunity to use the language either during or outside class.

(12) reveals in their study that many learners have confessed that they are still unable to speak fluently and appropriately despite having years of experience learning English. (13) identified several reasons why learners are reluctant to speak in a language class. First, inhibition seems to be an obstacle for learners to express themselves orally. They are fearful for making mistakes, being criticized by their peers as well as feeling uncomfortable of other students' attention onto them. Second, in order to speak freely without the feeling of apprehension, students need to have high motivation and be able to speak in a meaningful context. However, some learners find it difficult to speak due to limited vocabulary or correct grammatical structures to use.

To improve learners' speaking skill, language instructors have to help them to overcome their inhibition and increase their motivation level. (14) proposed in his study for instructors to formulate appropriate speaking activities which would help to decrease the anxiety of learners. Topics to be spoken is also deemed to be important in urging participants to feel comfortable, persuading them to speak English and increasing their confidence. To ensure learners are comfortable within their learning environment, (15) in his study about cooperative learning discovered that through interaction with others, learner have the opportunity to learn from their peers as they speak on issues or topics that are appealing. In another study by (16), to increase students' motivation or readiness to speak, positive attitudes need to be foregrounded. (17) further claimed that innovative speaking activities should be initiated by employing "authenticity, real-life simulation and meaningful tasks" which support the pedagogy of Communicative Language teaching. Earlier in another book, (18) also stated that to create positive impact on learners' speaking skill, instructors may adopt interesting, fun and motivating teaching strategies. To illustrate this point, (19) has utilized three, learner-centred communicative activities; discussion, problem-solving and role playing in her study to develop learners' speaking skills. She revealed that when students are placed in small groups among their peers, the learning atmosphere becomes encouraging for them to express themselves successfully as the objectives of their discussion is focusing on meaning rather than form. This shift of lesson objective has significantly reduced learners' level of apprehension while speaking. In addition, (20) conducted a study on using

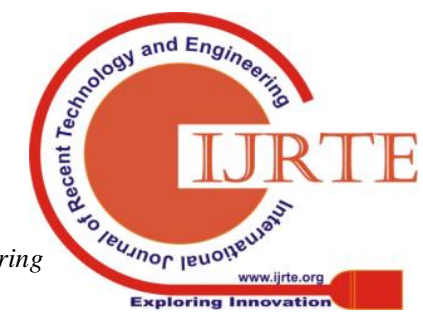


drama as a means to reduce learners' anxiety while speaking. Based on the feedback, he concluded that the use of drama indeed lowers the level of anxiety among learners and promote positive outcome and motivate learners to be continuously engaged in the process of language training.

\section{Bakhtin's notion of Ideological becoming}

Bakhtin (1981) used the term ideological becoming to explain the changing nature of the interlocutor's subjectivity during dialogic interaction. It can also be perceived how one develop the way we view the world, how we formulate our system of ideas or what Bakhtin defines as ideological self. The concept of Ideological becoming does not necessarily relate to a political edge, however, for one to achieve his ideological development, one also needs to develop his or her "political idea system" (21). The state of ideological becoming is achieved when he or she manages to transform his or her discourse from authoritative to internally persuasive. The term ideology embedded in the phrase is unnecessarily related to politics as it is initially defined as "developing ideas" within the context of Russian lexicon (22). Instead, Bakhtin refers to it as one's worldview and system of ideas. In another sense, Ideological becoming can be coined as the development of "ideological subjectivity" that is unbound by rigid ideas that are imposed through the "use of propaganda and coercive mechanisms" (23). During the process of Ideological becoming, one would transform as a wholesome and holistic individual as his or her worldview receives influence from the social context. This process also involves resistance and negotiation of meaning in maintaining the equilibrium between authoritative discourse and internally persuasive discourse. In addition, by being internally persuasive, one would learn to be critical towards new knowledge and to be actively engaged in "the logical layering of thought processes", therefore helping one to form his or her ideological self (22).

To achieve the state of Ideological becoming, one needs to be selective when assimilating words from others. (24) stated that IB involves one to interact with two different discourses: authoritative and internally persuasive discourses. When engaging in a dialogue or during the act of speaking, the speaker would be involved in an ideological process for language that we use reflects our perception of the world as well as our struggle to achieve social significance through the appropriation of others' words, language and discourses. These two discourses are discerned by its degree of ownership: assertion of authority and one's acquiescence to accept others' words and actions (25).

To elaborate further, authoritative discourse emerges when another's words are accepted and recited as we acknowledge its authority. For example, religious, political, moral (word): the word of a father, of adults and of teachers (24). It is fused with uncontested authority and as (26) elucidates, it demands "unconditional allegiance" for it does not allow its discourse to be appropriated and assimilated with our own words. Authoritative discourse seems to be distant and rigid for it does not offer any space for dialogue to frame it (26). A monologue is preferred by authoritative discourse so as to fit with the demand for the response to be alligned within the expectations of the speakers. The discourse would restrict the entry of opposing thoughts and interactions as it opines its reality is the one that matter. It is not to be challenged as it rests within an uncrossable zone which denies dialogue to occur. The authority of the discourse is bound to be unquestionable and uncontested. This discourse would attempt to disarm and overcome the desire for resistance and aggression. A discourse is perceived to be authoritative not merely because of the text but also referring to its culture, social and educational surroundings.

In contrast, similar to the notion of power by which it is always paired with resistance, authoritative discourse can be subjugated by the internally persuasive. Internally persuasive discourses are assimilated and interwoven with "one's own words" thus produced from within oneself in dialogic spaces that are "half-ours and half someone else's" (26). Internally persuasive discourse offer a place for questioning and interacting "with and without dogma" (24). According to Matusov, internally persuasive discourses enact 'dialogical questioning, testing and evaluation of statements (23), therefore, allows the individual to engage with authoritative discourse rather than passively absorb it. The non-finite nature of internally persuasive discourse is open for dialogues, thus new meaning emerges when one is engaged in it. The interplay between authoritative discourse and internally persuasive highlights the notion of Ideological becoming which refers to the ongoing process whereby individuals are actively engaged in a discursive community as they deal with "divergences among different discourses, negotiating new ways to mean, and finding perspective they can call their own" (24)).

To resist authoritative discourse marks one's ideological becoming in which one transforms an authoritative discourse into internally persuasive' that enables them to be critical in forming new knowledge or perspective. This process happens when we digest others' words from our own perspective. Internally persuasive discourse is known to be "genuinely dialogical" for its "open, flexible and dynamic" characteristics (25). When we merge our own words with the words of others, it creates creative, productive, new and independent words which do not remain in isolation. These new discourse would be applied to new contexts and contribute to one's ideological development as they also participate in intense interaction with other hegemonic discourses and ideological points of view.

\section{IMPLICATION FOR TEACHING AND LEARNING OF LITERATURE IN STIMULATING LEARNERS' SPEAKING SKILLS}

The interplay between authoritative discourse and internally persuasive in producing ideological becoming learners is relevant to be applied in literature classes, especially to stimulate students' speaking skills. (26) argued that within dialogic discourse different and contrasting ideas are inter-animated and open for exploration, thus this lead

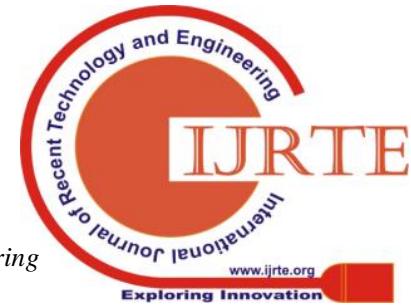


to occasions for learners to be expressive in asserting their views $(11,24,27)$ consider school language and literacy discourses as the authoritative voices in a classroom. In contrast, internally persuasive discourse is represented by the learners" "voices, desires and imaginations" (24). (11) stated that Internally persuasive discourse should be emphasized in educational setting for "learning is primarily social". Learners are involved with these two types of discourses during lesson, which Bakhtin defines as "dialogic process" where the learners "reciting by heart" and "re-telling in one's own words" (26). When learners recite by heart, it means they are passively repeating others' words. On the contrary, when learners re-tell using their own words, they are actively engaged in transforming meaning through "one's own tone, intonation and nuance" (24). The process of recitation and retelling represents the manner learners deal with authoritative discourse by positioning it within their internally persuasive discourses.

When dealing with literary texts, learners are required to do analysis and interpretation of the text according to its linguistic and contextual evidences. Literature provides space for learners to brainstorm and share their outlook on the intended text with their peers and instructors. By placing the students in small-group discussions, learners are confronted with multiple perspectives from their peers which would fuel their critical thinking as they weigh each viewpoint before arriving at their own personal responses. The tension between these two discourses invites learners to put forward their voice as the voice of authority (literary text) comes into contact with and inter-animate the voice of other (28). Within their discussion, learners are required to overcome authoritative discourse which does not offer avenue for inquiry and merge with their internally persuasive voice that constantly questions as new meanings are formed.

The interaction of their discourse is illustrated in Fig. 1 below:

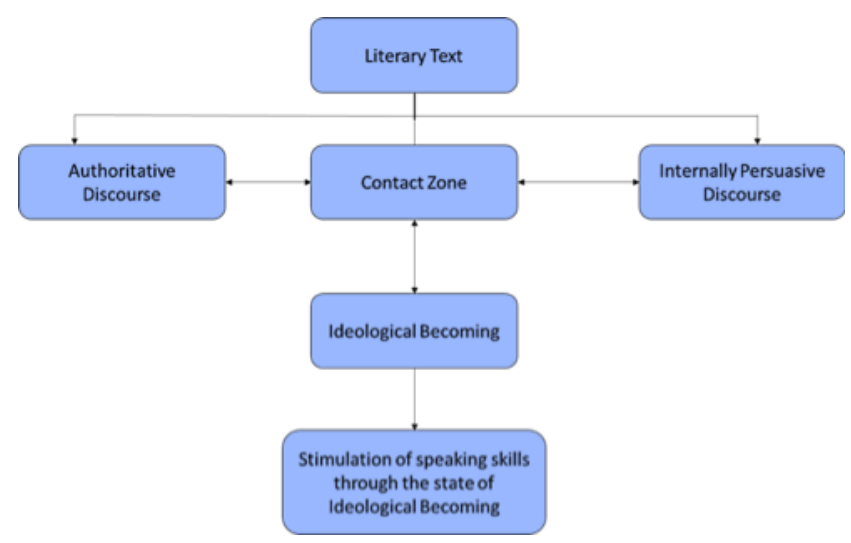

Fig. 1. Stimulation of speaking skill in literature lessons through the state of Ideological Becoming

\section{CONCLUSION}

The suggested model still needs to be refined upon conducting further empirical studies in order to test its suitability. In some studies, in regard to the application of Ideological becoming notion in education, the pedagogy may pose a challenge for learners to really achieve their state of Ideological becoming. Learners need to position themselves in a discursive community before they can assert their voice. In typical educational setting, students usually rely upon the voice of their teacher and whatever opinion they may form is usually poorly developed. Dealing with literary texts is already a challenge for the students, thus to ensure students are continuously engaged and dialogical with the different types of discourses before reaching their state of ideological becoming, instructors need to be able to lead the discussions so that it would invite multiple perspectives. These multiple perspectives offer avenue for learners to participate in a contact zone, in which they have to strategize while confronting authoritative discourses and merge them with their own voice or internally persuasive discourses. By introducing appealing literary text to the learners, they may be persuaded to speak and assert their viewpoints as they sub-consciously engage in the interplay of the state of Ideological becoming. In each literary text that students encounter and in each cycle of response and interpretation that they experience there is an opportunity for becoming that can be enriched by the voices and perspectives of others. Instructors of literature need to find ways to continuously nurture the process of ideological becoming as learners develop their critical and independent thinking from being constantly challenged during the process of text analysis, simultaneously motivating the learners to speak.

\section{REFERENCES}

[1] Murat Hişmanoğlu. Journal of Language and Linguistic Studies Vol.1, No.1, April 2005 Teaching English Through Literature Murat Hişmanoğlu. English [Internet]. 2005;1(1):53-66. Available from: http://www.doaj.org/doaj?func=abstract\&amp;id=817621

[2] Obeidat MM. Language vs. Literature in English Departments in the Arab World. 19 [Internet]. 1997;(January):30. Available from: http://dosfan.lib.uic.edu/usia/E-USIA/forum/vols/vol35/no1/p30.htm

[3] Custodio B, Sutton M. Literature-Based ESL for Secondary School Students. TESOL J. 1998;7(5):19-23.

[4] Hall G. Literature in Language Education. New York: Palgrave Macmillan; 2015.

[5] Carter R. Literature and language teaching 1986-2006: A review. Int J Appl Linguist. 2007;17(1):3-13.

[6] Elliot R. Encouraging reader-response to literature in esl situations. ELT J. 1990;44(3):191-8.

[7] Donato R, Brooks FB. Literary Discussions and Advanced Speaking Functions: Researching the (Dis) Connection. Foreign Lang Ann. 2004;37(2):183-99.

[8] Kramsch C, Kramsch O. The avatars of literature in language study. Mod Lang J. 2000;84(4):553-73.

[9] Mohamed A. A Review on Literature and its Place in Malaysia's Education. In: Bakar E, Abd Rahman E, editors. Curremt Trends, Issues and Challenges of Education and Language Studies. Kuala Lumpur: UPNM Press; 2019. p. 172-90.

[10] Kaur P, Mahmor N. Examining the Role of the English Literature Component in the Malaysian English Curriculum. Procedia - Soc Behav Sci [Internet]. 2014;134(May):119-24. Available from: http://dx.doi.org/10.1016/j.sbspro.2014.04.229

[11] Razmjoo SA, Ardekani SG. A Model of Speaking Strategies for EFL Learners. J Teach Lang Ski. 2011;3(3):115-42.

[12] Bueno A, Madrid D, McLaren N. TEFL in Secondary Education. Granada: Editorial Universidad de Granada; 2006.

[13] Leong L-M, Ahmadi SM. An Analysis of Factors Influencing Learners' English Speaking Skill. Int J Res English Educ. 2017;2(1):34-41.

[14] Boonkit K. Enhancing the development of speaking skills for non-native speakers of English. Procedia Soc Behav Sci [Internet] 2010;2(2):1305-9. Available from: 
http://dx.doi.org/10.1016/j.sbspro.2010.03.191

[15] Saborit JAP, Fernández-Río J, Cecchini Estrada JA, Méndez-Giménez A, Alonso DM. Teachers' attitude and perception towards cooperative learning implementation: Influence of continuing training. Teach Teach Educ. 2016;59(February 2018):438-45.

[16] Al-Jamal DA, Al-Jamal GA. An investigation of the difficulties faced by EFL undergraduates in speaking skills. English Lang Teach. 2013;7(1):19-27.

[17] Brown H. Teaching by Principles: An Interactive Approach to Language Pedagogy. San Francisco: Pearson; 2000.

[18] Terrell TD, Brown HD. Principles of Language Learning and Teaching. Vol. 57, Language. 2006. $781 \mathrm{p}$

[19] Oradee T. Developing Speaking Skills Using Three Communicative Activities (Discussion, Problem-Solving, andRole-Playing). Int J Soc Sci Humanit. 2013;2(6):533-5.

[20] Atas M. The Reduction of Speaking Anxiety in EFL Learners through Drama Techniques. Procedia - Soc Behav Sci. 2015

[21] Freedman SW, Ball AF. Ideological becoming: Bakhtinian concepts to guide the study of language, literacy, and learning. Bakhtinian Perspect Lang Literacy, Learn. 2004;(April):3-33.

[22] Aggarwal G. Mikhail Bakhtin and His Response to Authroritative Discourse. Contemp Educ Dialogue. 2015;12(1):87-109.

[23] Matusov E. Applying Bakhtin Scholarship on Discourse in Education: A Critical Review Essay. Educ Theory. 2007;57(2):215-37.

[24] Soo WL, Hassett D. The Multiple modes of Ideological Becoming: An Analysis of Kindergarteners' Appropriation of School Language and Literary Discourses. 2017;25(3):462-75.

[25] Tappan MB. Domination, subordination and thé dialogical self: Identity development and the politics of "Ideological becoming." Cult Psychol. 2005;11(1):47-75.

[26] Bakhtin M. The Dialogic Imagination: Four Essays. Austin: University of Texas; 1981.

[27] Scott PH, Mortimer EF, Aguiar OG. The tension between authoritative and dialogic discourse: A fundamental characteristic of meaning making interactions in high school. Sci Educ. 2006;90(4):605-31.

[28] Wertsch J. Voices of the Mind. Boston: Harvard University Press; 1991.

\section{AUTHORS PROFIE}

My name is Erda Wati Bakar, and affaliated with Language Centre, Universiti Pertahanan Nasional Malaysia, Kuala Lumpur, 51000, Malaysia, my area of interest is Linguistics and email me at :erdawati@upnm.edu.my

My good name is Ahmad Fahimi Amir, my current affaliatin is with Language Centre, Universiti Pertahanan Nasional Malaysia, Kuala Lumpur, 51000 , Malaysia. I am very much interested in languages. 